with a general stimulation of metabolic processes and. defence mechanisms.

Holböll and Herborg ${ }^{4}$ showed that intramuscular injections of sulphur constantly produced a leucocytosis from 20,000 to 30,000 per c.mm., the increase being due almost entirely to polymorphonuclear cells, and Power $^{5}$ demonstrated that in rabbits this was accompanied by a definite leucoblastic hyperplasia of the bone marrow. Such a polymorphonuclear leucocytosis was a constant feature in our patients. If such leucoblastic reaction is accompanied by an increased mobilization of bactericidal or other antibodies as Gay and Claypole ${ }^{6}$ believe, we may have a partial explanation of the beneficial effect of treatment. More obvious, however, are certain vascular changes which may be observed in the affected joints following the injections, for pain, tenderness, stiffness, and swelling are all temporarily.increased, and the skin becomes hot, red, and moist with perspiration. These cutaneous changes are also noticed to a less extent over the rest of the body, and it is possible that improvement in the joints may be the result of greater vascularity, accompanied by a corresponding increase in the capillary permeability and the lymph flow from the area. Such changes may be explained partly by the pyrexia (Davis and Petersen ${ }^{7}$ ).

Investigations by Mackay ${ }^{8}$ offer a reasonable explanation of the pyrexial reaction. He found that after intramuscular injections of sulphur into rabbits there follows in from twenty-four to forty-eight hours an acute tissue necrosis with debris formation, accompanied by a polymorphonuclear leucocytic infiltration, which subsides with regeneration and clearance of the debris in about thirteen days. He suggests that the fever is due to absorption of protein liberated by the necrosis at the site of the injection. It should be noted, however, that with the doses used in the treatment of chronic arthritis no residual disability in the injected muscles follows, and that pain and infiltration, should they occur, are always temporary, seldom lasting longer than twenty-four or thirty-six hours.

\section{Summary and Conclusions}

1. The treatment of chronic non-specific arthritis by intramuscular injections of sulphur is described, and its advantages over other pyrexial forms of therapy is discussed.

2. The cases considered form a group of fifty patients, in whom other mecognized forms of treatment (not including chrysotherapy') failed to give benefit.

3. The analysed results show that considerable improvement may be expected in a proportion of patients in whom the changes are limited to the soft structures about the joint, and are not permanent in nature. Less improvement is to be anticipated when damage of a permanent kind is present, such as involvement of bone and cartilage or partial dislocation and deformity.

4. A tendency to relapse when aetiological factors are still active is noted.

5. Certain contraindications to sulphur treatment are mentioned, particularly the acute phase of the disease.

6 . The mode of action is briefly discussed.

\section{REFERENCES}

${ }^{1}$ Meyer-Bisch, R., and Basch, E.: Biochem. Zeit., 1921, cxviii, 39. ${ }^{2}$ Schroeder, K.: Klin. Woch., 1927, vi, 2189.

s Cawadias, A. P.: Lancet, 1927, i, 1283.

4 Holböll, S. A., and Herborg, G.: Hospitalstidende, 1930, lxxiii, 1027.

s. Power, T. D.: Lancet, 1932, i, 338

-Gay, F. P., and Claypole, E. J.: Proc. Soc. Exp. Biol. and Med. $1914, x i, 47$.

'Davis, B. F., and Petersen,.W. F.: Journ. Exper. Med., 1917, xxvi, 699 .

-Mackay, R. P.: Arch. Neur. and Psychiatry, 1931, xxvi, 102.

\section{ACUTE BENIGN LYMPHOCYTIC MENINGITIS}

(ACUTE ASEPTIC MENINGITIS)

BY

\section{W. R. F. COLLIS, M.D., F.R.C.P.}

M.R.C.P.I., D.P.H.

PHYSICIAN to NATIONAL CHILDREN'S Hospital AND PAEDIATRICIAN TO ROTUNDA HOSPITAL, DUBLIN

A type of acute benign meningitis-as distinct from serous meningitis-has been recognized for some years on the Continent and in America. Little mention of the condition is to be found in the medical literature of Great Britain and Ireland, however, and no place has as yet been given it in English textbooks. Hence the cases given below and the following discussion should be of some general interest, as it appears that cases of recovery from a form of meningitis resembling tuberculous meningitis are not too uncommon here.

\section{Case Record}

A girl, aged $5 \frac{1}{2}$ years, was admitted to the National Children's Hospital on November 10th, 1934, complaining of severe headache and vomiting.

History. - The child had been quite well up to five days previously, when she had complained of headache, which became more severe at times; this was soon accompanied by vomiting, which had become very bad the night before admission, when the patient became delirious. The previous history showed that she had had pneumonia in infancy and whooping-cough two weeks prior to the present trouble. The father, mother, and other children were quite well. The mother stated that one of their children had died three years previously with somewhat similar symptoms, and that the doctor " had called it tetany."

Examination.-On admission the child appeared very ill and lay listless in bed. The temperature was $99.4^{\circ} \mathrm{F}$., the pulse 134, and the respirations 30 . Circulatory and respiratory systems showed nothing abnormal. There was some rigidity of the back and neck. The knee-jerks were present, but the left one was reduced. The right plantar reflex gave a flexor response, the left an extensor. No ankle-clonus was elicited. The ankle-jerks were present. Kernig's sign was positive on the right and negative on the left. The arm reflexes were not elicited. There was some loss of muscle tone on the left side. The eye movements were normal, the disks were not blurred, and the eye grounds were normal. Special examination of the ears by Mr. Wilson showed them to be perfectly healthy. The Mantoux tuberculin test was negative in a dilution of 1 in 100 old tuberculin. The white blood cell count showed 11,200 total leucocytes, the differential count being as follows: polymorphs $\mathbf{5 8}$ per cent., lymphocytes 39 per cent., monocytes 2 per cent., and eosinophils 1 per cent. A table showing the result of the cerebro-spinal fluid examinations is given below.

\begin{tabular}{|c|c|c|c|c|}
\hline Date... $\quad \ldots$ & $10 / 11 / 34$ & $-14 / 11 / 34$ & $28 / 11 / 34$ & $11 / 12 / 34$ \\
\hline $\begin{array}{c}\text { Protein } \\
\text { Globulin } \\
\text { increase }\end{array}$ & 0.03 gram $\%$ & $\begin{array}{l}0.09 \text { gram } \% \\
\text { Slight }\end{array}$ & $0.015 \operatorname{gram} \%$ & 0.015 gram $\%$ \\
\hline Chlorides ... & $0.66 \mathrm{gram} \%$ & 0.71 gram $\%$ & 0.72 gram \% & 0.71 gram $\%$ \\
\hline Sugar $\quad \ldots$ & - & Diminished & $\begin{array}{c}\text { Good reduction } \\
\text { Fehling's }\end{array}$ & $\begin{array}{l}\text { Poor reduction } \\
\text { Fehling's }\end{array}$ \\
\hline $\begin{array}{c}\text { Cytology } \quad . . . \\
\text { Monocytes } \\
\text { Polymorphs }\end{array}$ & \begin{tabular}{|c|}
$* 2,155$ cells per \\
c. mm. \\
$98 \%$ \\
$2 \%$
\end{tabular} & $\begin{array}{l}121 \text { cells per } \\
\text { c.mm. } \\
98 \% \\
2 \%\end{array}$ & $\begin{array}{c}9 \text { cells per } \\
\text { c.mm. } \\
-\end{array}$ & $\begin{array}{c}5 \text { cells per } \\
\text { c.mm. } \\
-\end{array}$ \\
\hline Z. N. Film & $\begin{array}{c}\text { No.T.B. seen } \\
\text { Negative }\end{array}$ & $\begin{array}{c}\text { No T.B. seen } \\
\text { Negative }\end{array}$ & $\overline{-}$ & $\overline{-}$ \\
\hline $\begin{array}{l}\text { Method of } \\
\text { Collection }\end{array}$ & $\underset{\text { Puncture }}{\text { Lumbar }}$ & $\begin{array}{l}\text { Cistern } \\
\quad \text { Punc:ure }\end{array}$ & $\underset{\text { Puncture }}{\text { Lumbar }}$ & $\underset{\text { Puncture }}{\text { Lumbar }}$ \\
\hline
\end{tabular}


Progress.-The child remained acutely ill for some two to three weeks, a general examination on December 2nd still showing little change: Kernig's sign was markedly positive on right side, less on left ; the plantar reflex was still extensor on left. After this, however, the child gradually improved, and by December 14th the Kernig and Babinski signs had cleared up, and the cerebro-spinal fluid was almost normal. Soon she was sitting up playing with her toys. Gradually she made a complete recovery. She has remained perfectly well ever since.

\section{Discussion}

At first the diagnosis of tuberculous meningitis was made, and the parents were given a grave prognosis, but as the child improved, and as repeated tuberculin reactions were negative (the Mantoux reaction was repeated after the child had recovered completely and was in good health, and was still negative), and as all examinations of the cerebro-spinal fluid, both by the direct method and by guinea-pig inoculation, never revealed tubercle bacilli, this diagnosis was no longer tenable. It was clear, also, that the case was not one of serous meningitis as described by the otologists, as the ears were normal and the cerebro-spinal fluid was not characteristic of that condition. Nor was any other condition, such as mumps, chicken-pox, measles, influenza, or herpeswhich are known sometimes to cause somewhat similar complications-found associated.

We were frankly puzzled, nor did any of the modern textbooks on paediatrics which we had to hand help us in any way (Holt and McIntosh, 1933 ; Garrod, Batten, Thursfield, and Paterson, 1934 ; and L. Parsons and S. Barling, 1933). Further study of the literature, however, revealed an interesting state of affairs. During the last twenty years a large number of cases with syndromes closely akin to the case reported above have appeared from time to time under such different titles as " meningiti. sierose e. meningisme," 1 " benign aseptic purulent meningitis," " " syndrome méninge avec lymphocytie rachidienne d'origine indéterminée," and "acute aseptic meningitis." Some of the cases varied somewhat in form, as those described by Guillain and Richet ${ }^{5}$ in 1910, the condition being associated with jaundice. Indeed, up till 1925 no syndrome which could be definitely felt to belong to a single disease had been clearly demonstrated. Then Wallgren ${ }^{4}$ described a small epidemic from Sweden, which he termed " une nouvelle maladie infectieuse du système nerveux central " (méningite aseptique aiguë).

The latter author has summarized the syndrome as follows :

1. There is an acute onset. The patient becomes rapidly gravely ill; symptoms and signs are those of meningitisfor example, vomiting, stiffness of the neck and back, headache, positive Kernig sign, and general convulsions sometimes occur. The eye signs are also variable-nystagmus, squint, photophobia, and papilloedema. Fever is usually present at the start, but the temperature returns to normal before the end of the second week.

2. The cerebro-spinal fluid shows the following features: (a) It is sterile. (b) There is a greai preponderance of lymphocytes-usually 150 to 250 -but sometimes more. (c) The sugar and chloride content is normal or almost normal.

3. The disease has a short duration, is benign and not followed by complications.

4. Parameningitic conditions, such as otitis, sinusitis, trauma, etc., are absent

5. Other associated conditions; such as mumps, herpes, encephalitis, or infectious diseases (typhoid or influenza), are not found.

Since this important communication was made in 1925 a fairly large number of cases have been described with the same definite syndrome by Anderson and Walff in Sweden $^{6}$; Gibbens in England ${ }^{7}$; Dereux in France $^{8}$; Du Bois 'in Switzerland'; Grun in Germany' ${ }^{10}$; Fornara in Italy $^{11}$; Viets and Watts in the United States ${ }^{12}$; and
Yoannovitch in Jugoslavia, ${ }^{13}$ to mention but a few. In a paper entitled "Acute Aseptic Meningitis" published in September, 1934, Viets and Watts give an able review of the literature, and add a number of cases of their own. Finally they sum up the present position in regard to the question as follows:

"The disease known as acute aseptic meningitis, first clearly described by Wallgren, has now found a well-marked place in medical literature, and should be considered as a clinical entity, as no definite relationship has been shown to exist between it and other diseases."

The case recorded above was brought down to the Royal Academy of Medicine of Ireland, and also described at the 1935 meeting of the British Paediatric Association. At both meetings a number of physicians stated during the discussion that they had seen exactly similar cases from time to time, all of which they had diagnosed as tuberculous meningitis, but about which they laterr had to modify their opinion when the patient made a complete recovery.

\section{A FURTHER CASE}

Recently Professor Synge diagnosed a case which was admitted to the City of Dublin Hospital under his care as one of acute aseptic meningitis, and has given me permission to quote it here.

A girl, aged $9 \frac{1}{2}$ years, was admitted to hospital on March 23rd, 1935, giving a three-day history of severe headache and vomiting, which had increased until she was semiconscious. The father had died from meningitis.

Physical examination showed that the pupils reacted sluggishly to light, there was a stiff neck, Kernig's sign was positive, the knee-jerks reduced, and the plantar responses flexor. The ears were carefully examined and nothing abnormal was found. All other systems in the body were normal. The cerebro-spinal fluid showed an increase in globulin, the chloride figure was 720 , and the cells $500-$ mostly lymphocytes and some polymorphs. - No tubercle bacilli were found.

Several other lumbar punctures were done. Gradually the child recovered, and was discharged perfectly well one month after admission. Professor Synge stated that the normal chlorides made him first think that the case would probably turn out to be one of acute aseptic meningitis.

\section{Conclusion}

It would appear, then, that such cases are by no means medical curiosities, but are of fairly common occurrence. No case has as yet come to necropsy, and the few animal experiments which have been done are not sufficiently conclusive, as yet, to warrant any very definite theory as to the aetiology of the disease.

Eckstein $^{14}$ injected three monkeys (into the cisterna magna). One monkey developed fever and became paralysed in the hind legs. Its cerebro-spinal fluid showed a preponderance sometimes of polymorphonuclear cells and sometimes of lymphocytes. The injection of the cerebro-spinal fluid from this monkey into another produced a similar state in the second animal. Du Bois," by injecting albumin into rabbits intravenously, produced a cerebro-spinal fluid characterized by an increase in lymphocytic cells. He suggested that the disease was due to a generalized-lesion of the reticulo-endothelial systems. Knauer ${ }^{15}$ placed some of the fluid from a patient with the condition on the scarified cornea of a number of rabbits without result, and held that the condition was therefore not due to virus of encephalitis.

It seems, however, that there exists a definite clinical entity which we must conclude is caused by a virus as yet undiscovered, and that as such it deserves a place in modern medical textbooks, particularly as it is apt to be confused with tuberculous meningitis, with the result that a very grave prognosis is given to the relatives, who thereby experience much unnecessary suffering. The title "acute aseptic meningitis" is clearly not too satis- 
factory, as the word aseptic would imply no organism or virus as the causal agent. As we have stated above, it is probable that some virus as yet unidentified is the infective factor. Hence the purely descriptive name of " acute benign lymphocytic meningitis" is submitted as a more accurate title for the condition.

\section{Summary}

1. Two cases of acute benign lymphocytic meningitis are described.

2. A review of the literature on the subject is given, and a plea is made that the disease syndrome of the condition as described by $\mathrm{A}$. Wallgren in 1925 should be recognized by modern paediatric textbooks.

My thanks are due to Professor V. M. Synge for allowing me to publish one of the cases, and to Drs. H. L. Parker and A. Wallgren for their help and advice regarding the literature.
REFERENCES

${ }^{1}$ Fornara, P.: Communicazione all' XI Congresso Pedatricc Italiano, Milan, October, 1924

'Schill, E.: Monatschr. f. Kind., 1930, xlviii, 434.

${ }^{3}$ Laubry, Ch., and Foy, G.: Bull. et Mém. Soc. Méd. des Hôp. dı Paris, October, 1910 , p. 230.

4 Wallgren, A.: Acta Paediatrica, 1925, iv, 158

${ }^{5}$ Guillain, G., and Richet, Ch.: Bull. et Mém. Soc. Med. des HSp. de Paris, October, 1910, xxx, 289.

de Paris, October, 1910, xxx, 289 . xcii, 572.

'Tibbens, 5 .

${ }^{8}$ Dereux, J.: Journ. de Méd. de Paris, January 15th, 1931, p. 50.

Du Bois: Rev. Méd. de la Suisse Romande, 1931, li, 617.

${ }_{11}^{10}$ Grun, R.: Deut. Arch. f. klin. Med., 1932, clxxii, 429.

${ }^{11}$ Fornara, P.: Est. d. Rivista Ospadaliera, 1926, xv, 19.

2 Viets, H. R., and Watts, J. W.: Journ. Nerv. and Ment. Dis. September, 1934, lxxx, No. 3, 253.

${ }^{13}$ Yoannovitch, G.: Bull. Off. Internat. d'Hy'g. Publique, April 1931 , p. 675 .

${ }^{14}$ Eckstein, A., Hottinger, A., and Schlerssing, H.: Zeit. f. klin. Med., 1932, cxviii, 97

${ }^{51}$ Knauer, H.: Klin. Woch., March 12th, 1932, Part I, p. 449.

\section{ACUTE FREE PERFORATION OF THE GALL-BLADDER

\author{
BY
}

A. L. D'ABREU, M.B., Сн.B., F.R.C.S.

SENIOR ASSISTANT IN THE SURGICAL LNIT, THE WELSH NATIONAL SCHOOL OF MEDICINE, CARDIFF

The expectant or delayed treatment of acute cholecystitis, whereby operation is postponed until the acute inflammatory phase is over, gives such excellent results that there is a danger of its being adopted too complacently. In unfavourable cases suppuration and gangrene may be followed by perforation of the gall-bladder, leading to fistulous communication with other viscera, such as the stomach, duodenum, small intestine, colon, or rarely the lung, or to the formation of a pericholecystic abscess, or to a general flooding of the peritoneal cavity by bile. Acute free perforation of the gall-bladder is the description applied to this last catastrophe.

Free extravasation of bile is held to be uncommonly rare; it has, however, been noted three times in the last 116 cases of gall-bladder disease met with in this unit at operation or at post-mortem examination (cases diagnosed as cholecystitis but not confirmed by operation have been excluded). This seemingly high incidence is supported by figures from other clinics, mostly American, and will be discussed later: in the same series of 116 cases perforation with the formation of a localized abscess was noted once, while no case of fistulous communication occurred.

CASE I.-Rupture of Gall-bladder: General Biliary Peritonitis : Drainage and Ileostomy: Death

A man, aged 57, was admitted to the Surgical Unit on January 4th, 1930, as an emergency; he was almost moribund, and unable to give a coherent history. A recent recurrence of a right inguinal hernia, which had been operated upon seven years previously, had been followed two days before admission by sudden generalized abdominal pain and vomiting; his doctor found and reduced a large swelling in the scrotum, but without relieving his symptoms; he was therefore sent to hospital, extremely ill, pale, and collapsed, with a subnormal temperature and a pulse of 62 . The abdomen was immobile and retracted, with generalized rigidity and tenderness; no abnormal dullness was detected. A right inguinal hernia was reduced with ease ; a diagnosis of general peritonitis having been made, Mr. Lambert Rogers opened the abdomen by a right paramedian incision; bile-stained fluid was encountered, but the rupture in the gall-bladder was not easily seen. The intestines were reddened and very distended. As the patient's condition was so bad an ileostony was rapidly done and the abdomen closed with appropriate drainage. The patient died the same day.

Necropsy.-Old perihepatitis was present; the gall-bladder showed an acute free perforation of the fundus; there were no gall-stones present, and the common bile duct was patent. Rupture had occurred in an inflamed gall-bladder.
CASE II.-Acute Calculous Cholecystitis : Rupture: General Biliary Peritonitis: No Operation: Death

A pensioner, aged 75, was admitted to the Surgical Unit as an emergency on September 5th, 1934. Twelve days before admission the right leg had swollen, and phlebitis had been diagnosed. Nine days later, following an acute attack of upper abdominal pain, he became cyanosed and very short of breath. In view of his age and the existence of arteriosclerosis, a cardiac condition was held to be responsible for the symptoms. The pain gradually subsided, but later returned. He vomited twice on the day before admission. There was no jaundice and no urinary disturbance.

On admission he was flushed, restless, and cyanosed, with temperature of $99.8^{\circ} \mathrm{F}$., a pulse of 140 , and respirations 40 . The tongue was heavily coated; the left ankle was swollen and tender. The abdomen did not move on respiration, and showed some rigidity on the right side; tenderness was general. No masses nor any visceral enlargements could be felt, and the liver dullness was normal. Tenderness was not more marked over the gall-bladder or appendix than elsewhere. The heart was normal in size, but the pulse was irregular. Rhonchi were heard all over the lung fields; the urine contained a haze of albumin. In consultation with my senior colleague, Mr. Lambert Rogers, a provisional diagnosis of acute pancreatitis was made. Following the teaching of the late Mr. John Murray, cases of that disease had been treated in this unit by conservatism in several instances with success, and in view of the age and extremely precarious condition of this patient operation was withheld. Small doses of morphine and atropine, combined with continuous rectal saline and glucose, were given. The next day the patient showed some clinical improvement; the pain and rigidity were less. On the following day, however, the patient collapsed and died.

Necropsy.-A general peritonitis associated with free bile and gall-stones in the peritoneal cavity was present. A small contracted gall-bladder, containing many stones, was gangrenous and had perforated; there was recent perihepatitis; the liver showed a fine cirrhosis; the myocardium showed fibrous replacement; and there was a bronchopneumonia of both lungs.

\section{CASE III.-Calculous Cholecystitis : Acute Free Perforation of the Gall-bladder: General Peritonitis: Cholecystostomy : Recovery}

A married woman, aged 71 , was admitted on November 27th, 1934, as an emergency. A week before admission she suffered suddenly with severe colicky pain in the upper abdomen on the right side, and vomited; the pain persisted. She was an enfeebled old lady who gave a poor history. On admission she looked ill and in much pain, with a temperature of $100.6^{\circ} \mathrm{F}$., pulse 88 , and respirations 22 . The abdomen was well covered with fat. Tenderness and rigidity were marked in the right hypochondrium, but no mass could be felt.

A diagnosis of calculous cholecystitis was made, and conservative treatment, including the Fowler position, morphine and atropine, and continuous rectal saline, was employed. On the following day the condition was worse: the tempera- 